\title{
Formulation of a Tropical Beverage by Applying Heat Treatment and High Hydrostatic Pressure
}

\section{Carla Marengo-Orozco $\bullet$, Martha Patricia Tarazona-Díaz*® and Ligia Inés Rodríguez®}

Process Engineering and Industrial Systems Research Group, Department of Engineering, Jorge Tadeo Lozano University, Carrera 4 No 22-61, 110311 Bogotá, Colombia

Received: 23 July 2019 Accepted: 7 August 2020

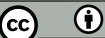

${ }^{*}$ Corresponding author:

Phone: (+571)2427030

Fax: (+571)5612107

E-mail:marthap.tarazonad@utadeo.edu.co

\section{SUMMARY}

Research background. Passion fruit and carrot have a good antioxidant capacity; however, their consumption is low. There is no information on their use in beverages or in processes such as high hydrostatic pressure, which provides the safety of the drink without affecting its quality.

Experimental approach. In this study the effect of high hydrostatic pressure (HHP; 500 MPa for $250 \mathrm{~s}$ at $25^{\circ} \mathrm{C}$ ) and thermal processing (at $65^{\circ} \mathrm{C}$ for $10 \mathrm{~min}, 75^{\circ} \mathrm{C}$ for $2 \mathrm{~min}$ and $95^{\circ} \mathrm{C}$ for $1 \mathrm{~min}$ ) were evaluated in the formulation of a cold-pressed beverage from purple passion fruit, green passion fruit and carrot juice, taking into account antioxidant capacity, vitamin C concentration, sensorial evaluation and microbiological growth at $8^{\circ} \mathrm{C}$.

Results and conclusions. The formulation containing $67 \%$ purple passion fruit, $17 \%$ green passion fruit and $17 \%$ carrot was the one that stood out with its antioxidant capacity, high vitamin C concentration and sensorial evaluation. The HHP treatment preserved the antioxidant capacity and vitamin $\mathrm{C}$ concentration, and resulted in the best scent. Juices stored at $8^{\circ} \mathrm{C}$ did not show microbial growth.

Novelty and scientific contribution. In this study, we used tropical raw materials with good sensory acceptance and antioxidant capacity that could be used in the production of high value-added foods. Additionally, the research demonstrated that HHP is a conservation method that maintains the antioxidant capacity, vitamin $C$ and aroma of the beverage to a greater extent than thermal treatments; the latter is of interest for its use in minimally processed products and functional food.

Key words: purple passion fruit, green passion fruit, carrot, high hydrostatic pressure, antioxidant capacity

\section{INTRODUCTION}

Fruits are a good source of antioxidants with therapeutic properties against diseases such as cancer (1), obesity (2) and Alzheimer's (3), among others. Although these studies (1-3) are related to isolated substances from fruits and are conducted in cell culture or animal models, they provide insights into the possible prevention of these chronic diseases. They encourage the consumption of not only fruits and vegetables, but also of derived products such as natural juices (4) and their mixtures $(5,6)$, providing new flavours and possible synergistic effects on the antioxidant capacity of such matrices $(7,8)$.

Pasteurization is the most common method in the food industry; nevertheless, it can reduce the quality; for example, in non-centrifuged watermelon juice, pasteurization (87.7 ${ }^{\circ} \mathrm{C}, 20$ s) significantly reduced the colour index, bioactive compounds such as lycopene, antioxidant capacity and total polyphenols, and the sensory quality of the juice, particularly during storage for 30 days at $8^{\circ} \mathrm{C}$. The juice was microbiologically safe for up to 30 days when stored at 4 or $8^{\circ} \mathrm{C}$ (9). Additionally, there is a relationship between the thermal processing and the bioavailability of the bioactive compounds in the organism. For example, thermal processing could react with other compounds present in the watermelon juice, such as sugars, to form nutritionally unavailable derivatives, such as products generated in the Maillard reaction, reducing the percentage of absorption. In this way, 
the pasteurization $\left(80^{\circ} \mathrm{C}, 40 \mathrm{~s}\right)$ decreased the absorption percentage of L-citrulline in human colon cancer cells (Caco-2) (10). Other authors mention that thermal processing can degrade bioactive compounds $(11,12)$ and modify organoleptic properties (13). For this reason, other preservation alternatives have been developed that ensure the safety of food without affecting its quality. One of them is the use of high hydrostatic pressure (HHP), which is a non-thermal method based on the application of pressure on the food matrix, able to reduce the microbiological load, preserve the organoleptic properties and bioactive compounds in the product $(14,15)$. This technology has been used in natural products and functional food (16) so that the compounds of interest can reach the consumer without degrading during processing.

The present study focuses on the formulation of beverages with greater antioxidant capacity and vitamin $C$ content from the mixture of purple passion fruit (Passiflora edulis $\mathrm{f}$. edulis Sims), green passion fruit (Passiflora maliformis) and carrot (Daucus carota) because these fruits have demonstrated high antioxidant capacity (17-19). It also evaluates the effect of $\mathrm{HHP}\left(500 \mathrm{MPa}, 250 \mathrm{~s}, 25^{\circ} \mathrm{C}\right)$ with respect to three conventional thermal processings (at $65^{\circ} \mathrm{C}$ for $10 \mathrm{~min}, 75^{\circ} \mathrm{C}$ for $2 \mathrm{~min}$, and $95^{\circ} \mathrm{C}$ for $1 \mathrm{~min}$ ). Subsequently, we carried out a sensorial analysis and microbiological follow up at $8{ }^{\circ} \mathrm{C}$ on the formulations that gave the best results to determine the best conservation method and the best formulation according to the perception of potential consumers, antioxidant capacity, vitamin C content and microbiological parameters.

\section{MATERIALS AND METHODS}

\section{Chemicals and reagents}

The reagents were of analytical grade, except for $96 \%$ methanol and $96 \%$ ethanol, which were of industrial grade, and provided by Ciacomeq (Bogotá, Colombia). Citric acid, 37 $\%$ hydrochloric acid, L-ascorbic acid, glacial acetic acid, sodium acetate, sodium nitrite, sodium hydroxide and iron(III) chloride hexahydrate were obtained from Merk S.A. (Bogotá, Colombia). Trolox (6-hydroxy-2,5,7,8-tetramethylchroman-2-carboxylic acid), TPTZ (2,4,6-tripyridyl-s-triazine), DPPH (2,2-diphenyil-picrylhydrazyl) and 2-nitroaniline were provided by Auros Químicos Ltda (Bogotá, Colombia), and oxalic acid by Carbo Erba Reagents S.A. (Sabadell, Spain).

\section{Vegetal material and sample preparation}

The vegetal material: purple passion fruit, green passion fruit and carrot was obtained from the local market and kept at $8{ }^{\circ} \mathrm{C}$ in the laboratory of the Jorge Tadeo Lozano University, Bogotá, Colombia, until its processing. Subsequently, the raw material was washed with potable water and disinfected with a solution of sodium hypochlorite $100 \mathrm{mg} / \mathrm{L}$ and citric acid 0.2 $\mathrm{g} / \mathrm{L}$ for $5 \mathrm{~min}$. Additionally, it was necessary to immerse the carrots in an anti-browning solution (ascorbic acid $10 \mathrm{~g} / \mathrm{L}$ and citric acid $2 \mathrm{~g} / \mathrm{L}$ ). Afterwards, the juice was extracted from the obtained pulp by a cold pressing equipment (Norwalk Juicer 280; Bentonville, AR, USA).

\section{Effect of the preservation method on the antioxidant capacity and vitamin C content in the mixtures}

An enhanced $\{3,2\}$ simplex lattice design (20) was proposed to study the effect of the three components (juices of purple passion fruit, green passion fruit and carrot) on the antioxidant capacity and vitamin $C$ concentration of the mixtures. First, the juices were submitted to HHP using a high-pressure processing equipment (Hiperbaric HPP, Miami, FL, USA) at $500 \mathrm{MPa}$ for $250 \mathrm{~s}$ at $25^{\circ} \mathrm{C}$ (these working conditions were defined by preliminary tests, data not shown). Pasteurisation was evaluated under three different time and temperature conditions $\left(\mathrm{P}_{1}=65^{\circ} \mathrm{C}\right.$ for $10 \mathrm{~min}, \mathrm{P}_{2}=75^{\circ} \mathrm{C}$ for 2 min and $P_{3}=95^{\circ} \mathrm{C}$ for $1 \mathrm{~min}$ ), with a subsequent thermal shock at $10^{\circ} \mathrm{C}$. Pasteurisation was carried out in an oil bath (Memmert, Schwabach, Germany) controlled by a thermostat by immersing the glass containers with the samples.

The response variables were the antioxidant capacity expressed in mg of Trolox equivalents (TE) per $L$ of beverage, according to the FRAP and DPPH methods, and vitamin $C$ concentration expressed in $\mathrm{mg}$ L-ascorbic acid per $\mathrm{L}$ of the beverage. The design consisted of 10 random combinations; 3 with only one component, 3 binary mixtures and 4 comprising all three juices (Table 1). In addition, the samples of a single component and the one that contained all the ingredients in equal amounts were done in duplicate.

To quantify the antioxidant capacity, the sample was diluted 1:10 with $80 \%$ methanol for DPPH and $80 \%$ ethanol for FRAP assay. Afterwards, the diluted solutions were centrifuged at $2800 \times g$ for 15 min (centrifuge Rotofix 32; Hettich, Schwerin, Germany) and the supernatant was taken. For vitamin C quantification, the samples were treated with a $0.15 \%$ oxalic acid solution in sufficient quantity according to Bernal de Ramírez (21) to provide a concentration between 0.04 and $4 \mathrm{mg}$ L-ascorbic acid per $\mathrm{mL}$. Then, the samples were centrifuged at $2800 \times g$ for 15 min (Rotofix 32; Hettich) and the supernatant was taken.

\section{Determination of the antioxidant capacity by FRAP assay}

Ferric reducing antioxidant power (FRAP) assay is useful for the determination of antioxidants present in a liquid sample. It is based on the reduction of the iron(III)-tripyridyltriazine to iron(II)-tripyridyltriazine with antioxidants (reducing agents) in acidic solution. This assay was carried out in triplicate according to the method described by Benzie and Strain (22) as follows: $30 \mu \mathrm{L}$ of diluted extract were mixed with 30 $\mu \mathrm{L}$ of $80 \%$ ethanol and $940 \mu \mathrm{L}$ of FRAP reagent (composed of $0.3 \mathrm{~mol} / \mathrm{L}$ buffer sodium acetate, $\mathrm{pH}=3.6,0.01 \mathrm{~mol} / \mathrm{L}$ tripyridyltriazine and $0.02 \mathrm{~mol} / \mathrm{L}$ iron(II) chloride (10:1:1)). Then, the sample was incubated at $37^{\circ} \mathrm{C}$ for $1 \mathrm{~h}$ in the absence of light. Subsequently, the absorbance was measured at $593 \mathrm{~nm}$ in the spectrophotometer (Evolution ${ }^{\mathrm{TM}}$ 300; Thermo Fisher Scientific, 


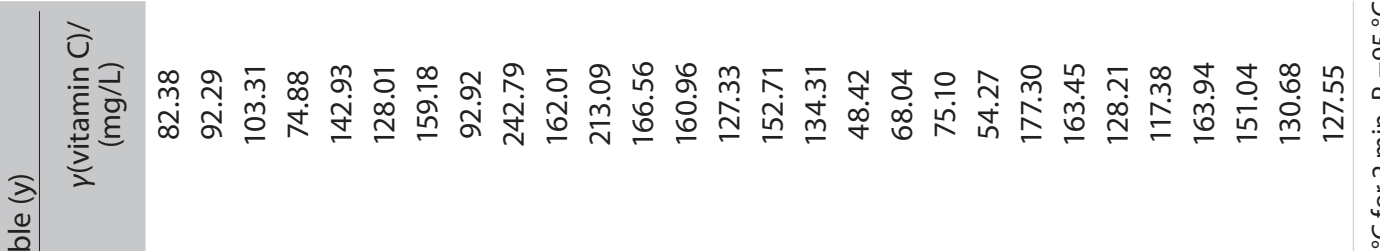

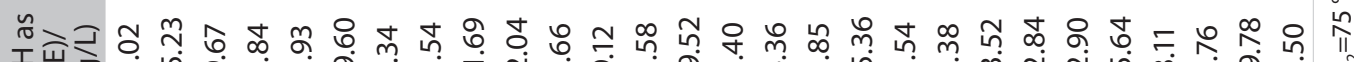

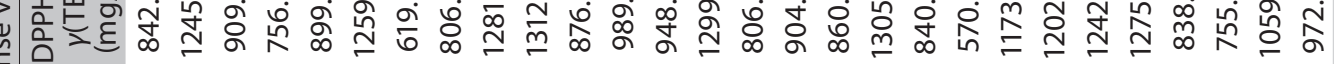

ญे

产 ๘

政

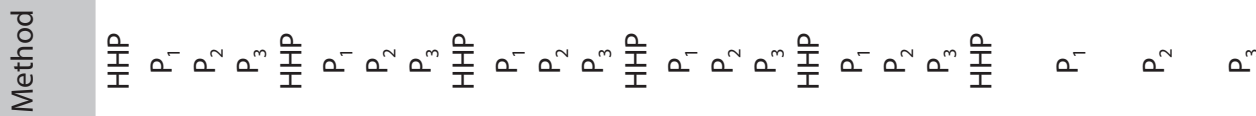

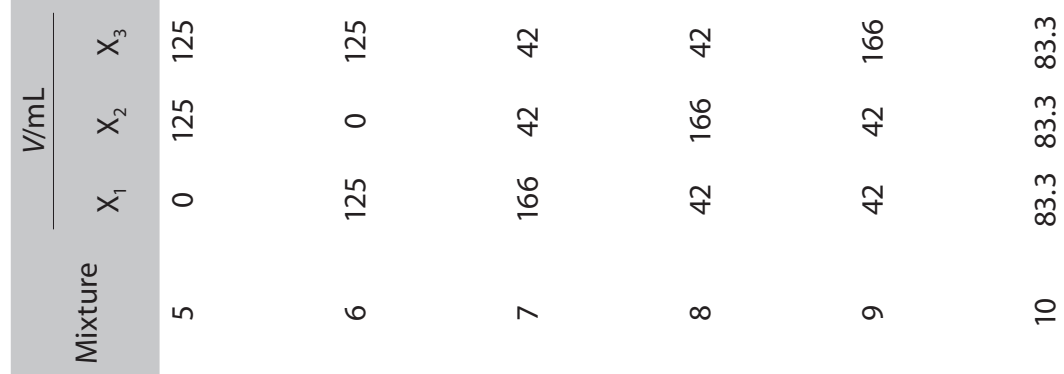

б

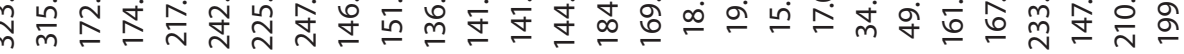

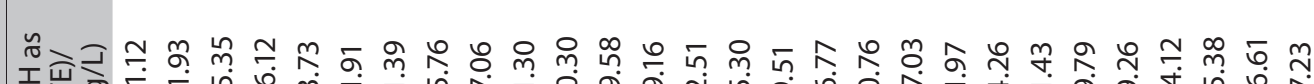

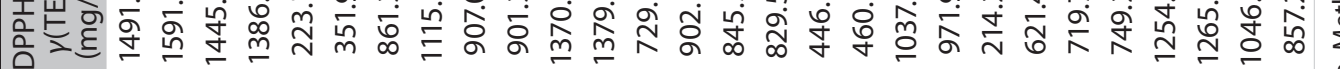

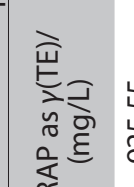

นnก

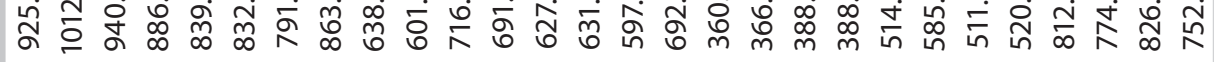
采

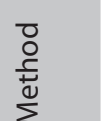

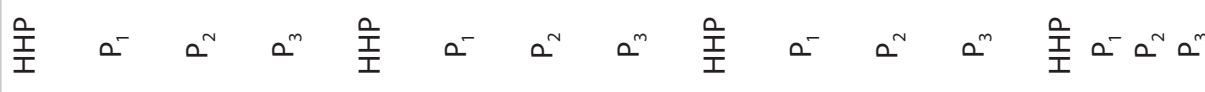


Loughborough, UK) and it was compared with a Trolox standard linear curve between 100 and $600 \mu \mathrm{mol} / \mathrm{L}$. The antioxidant capacity was expressed as Trolox equivalent in $\mathrm{mg} / \mathrm{L}$.

\section{Determination of antioxidant capacity by DPPH assay}

This method is based on the reduction of stable DPPH nitrogen radicals in the presence of antioxidants. Antioxidant capacity was determined according to the method described by Brand-Williams et al. (23) in triplicate. A volume of $50 \mu \mathrm{L}$ of diluted extract, $800 \mu \mathrm{L}$ of $80 \%$ methanol and $200 \mu \mathrm{L}$ of methanol solution of $6 \cdot 10^{-4} \mathrm{~mol} / \mathrm{L}$ DPPH were mixed. Then, the mixture was incubated at $37^{\circ} \mathrm{C}$ for $1 \mathrm{~h}$ in the absence of light. The absorbance was measured at $515 \mathrm{~nm}$ (Evolution ${ }^{\mathrm{TM}}$ 300; Thermo Fisher Scientific) and compared to a Trolox calibration curve in the concentration range from 100 to $600 \mu \mathrm{mol} / \mathrm{L}$. The results were expressed as Trolox equivalents in $\mathrm{mg} / \mathrm{L}$.

Determination of vitamin C using 2-nitroaniline colourimetric method

The L-ascorbic acid is treated with 2-nitroaniline diazotized in the presence of an excess of $\mathrm{NaOH}$, which turns to 2-nitrophenylhydrazine and gives a red-violet sodium salt solution with absorption maximum at $540 \mathrm{~nm}$. Vitamin C was determined according to the method described by Bernal de Ramírez (21) in triplicate. For this assay, the components were added in the following order: $10 \mu \mathrm{L}$ of 2-nitroaniline reagent, $20 \mu \mathrm{L}$ of sodium nitrite, $380 \mu \mathrm{L}$ of $96 \%$ ethanol, $50 \mu \mathrm{L}$ of diluted extract, $50 \mu \mathrm{L}$ of $0.15 \%$ oxalic acid, $120 \mu \mathrm{L}$ of $10 \% \mathrm{NaOH}$ and $380 \mu \mathrm{L}$ of distilled water. The absorbance was then measured at 540 nm (Evolution ${ }^{\text {TM }}$ 300; Thermo Fisher Scientific). It was compared to L-ascorbic acid calibration curve in the concentration range from 20 to $200 \mathrm{mg} / \mathrm{L}$. The results were expressed in $\mathrm{mg} / \mathrm{L}$ of L-ascorbic acid.

\section{Sensory and microbiological analyses}

The formulations containing the three ingredients (mixtures 7, 8, 9 and 10 in Table 1) were subjected to the four conservation methods ( $\mathrm{HHP}, \mathrm{P}_{1}, \mathrm{P}_{2}$ and $\mathrm{P}_{3}$ ). These samples were taken for sensory evaluation of colour, aroma, taste and general acceptance. The test was conducted with an informal sensory panel consisting of 30 people (15 women, 15 men, aged between 20 and 28). The tests were carried out with the products at $20^{\circ} \mathrm{C}$ using a seven-point hedonic scale where $7=$ like a lot, $5=$ like a little, $4=$ dislike, 3 =dislike a little, and $1=$ dislike it a lot, with a marketing limit set at 5 .

The mixtures containing the three raw materials according to the enhanced simplex lattice design (Table 1) were subjected to the four conservation methods and then stored at $(8 \pm 2)^{\circ} \mathrm{C}$. Every 15 days, during 60 days, total mesophilic aerobic bacteria were counted on plate count agar, and moulds and yeasts on potato dextrose agar. The results were expressed as colony forming units per $\mathrm{mL}$. The microbiological parameters were determined in triplicate.

\section{Statistical analysis}

The response surface methodology was used to determine the effect of conservation methods on antioxidant capacity and vitamin $C$ content in the formulations. The experimental design was carried out with program Design-Expert, v. 9.0 (24). The choice of the response function that best fitted the experimental data was made using ANOVA $(p<0.05)$, considering the linear, quadratic, cubic and special quartic models. After the analysis of the model, the associated contour graphs were generated, and the best mixing conditions were defined.

To determine the effect of conservation methods and the formulation on the sensorial evaluation, the Kruskal Wallis $(p<0.05)$ test was carried out with the statistical program Infostat, v. 2018e (25), performing the Mann-Whitney U test $(p<0.0083)$ in the case of the occurrence of a significant difference.

\section{RESULTS AND DISCUSSION}

\section{Antioxidant capacity and vitamin C concentration in the mixtures}

FRAP assay

Regression analysis of the results obtained for the determination of antioxidant capacity with FRAP assay (Table 1), shows good linearity with high coefficients of determination (Table 2) ( $R_{\text {adj }}^{2} \geq 0.86$ and model with $p \leq 0.0014$ in test $F$ ), which implied that the variability in the antioxidant capacity of the beverage is explained to a high degree by its components. Additionally, according to the contour graphs (Fig. 1), component $X_{1}$ (purple passion fruit) is the largest contributor to the antioxidant capacity, while formulations with a high carrot content (component $X_{3}$ ) had a lower value in the response variable. Nevertheless, according to Fig. 1c, there is a synergistic effect between these components. Fig. $1 \mathrm{a}$ also shows a similar behaviour of the green passion fruit $\left(X_{2}\right)$ and $\operatorname{carrot}\left(X_{3}\right)$ because the mixtures with high content of these raw materials have a greater antioxidant capacity than what has been reported for the pure juices from these fruits.

The conservation methods also affected the antioxidant capacity of the formulations. Treatments with HHP and $\mathrm{P}_{2}$ gave the highest values (Fig. $1 \mathrm{a}$ and $1 \mathrm{c}$ ), while the method $\mathrm{P}_{3}$ (Fig. 1d) showed the lowest results in the trial, which could be explained by the fact that the high temperatures of the process can degrade some antioxidant compounds $(11,12)$. On the other hand, sample 6 , which was subjected to $P_{2}$ method, had the highest antioxidant capacity expressed as Trolox equivalents ( $927.96 \mathrm{mg} / \mathrm{L}$; Table 1). The above demonstrates the potential of the beverage with respect to other products on the market, with higher values than blueberry juice type Toro $(0.77 \pm 0.01) \mathrm{mg} / \mathrm{g}$ ) obtained by Kraujalytè et al. (26), and Veltlín zelený white wine ((535.62 \pm 2.50$) \mathrm{mg} / \mathrm{L})$, but lower than Modrý Portugal red wine ((1231.43 \pm 2.50$) \mathrm{mg} / \mathrm{L})$ characterized by Stratil et al. (27). In addition, the antioxidant capacity of the 


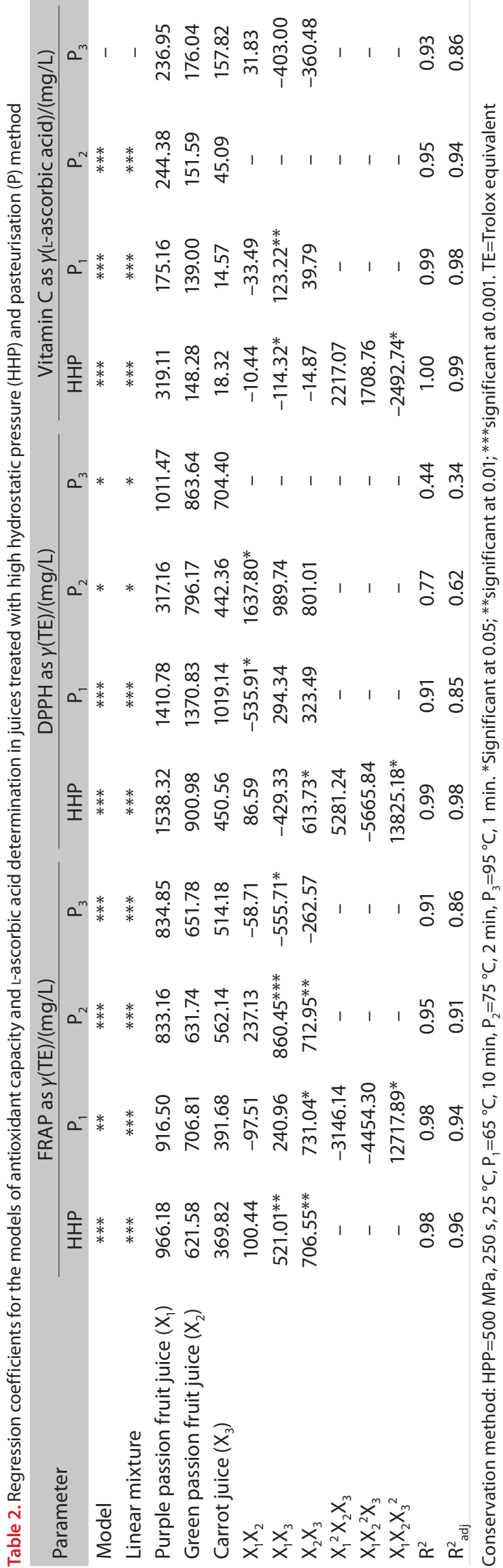

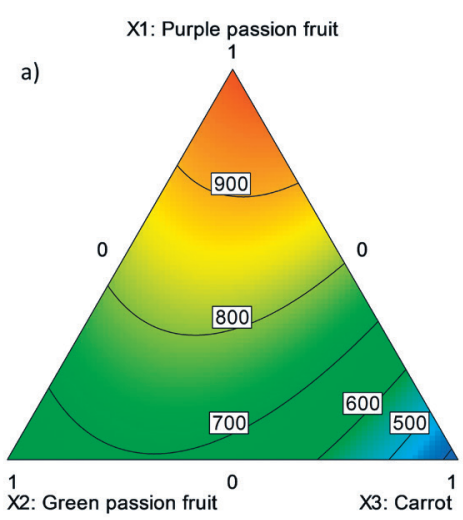

X1: Purple passion fruit

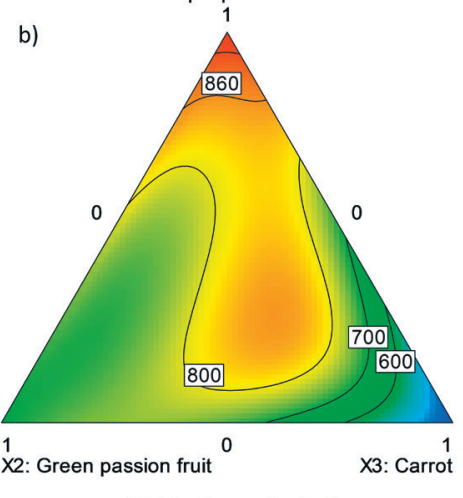

X1: Purple passion fruit

c)
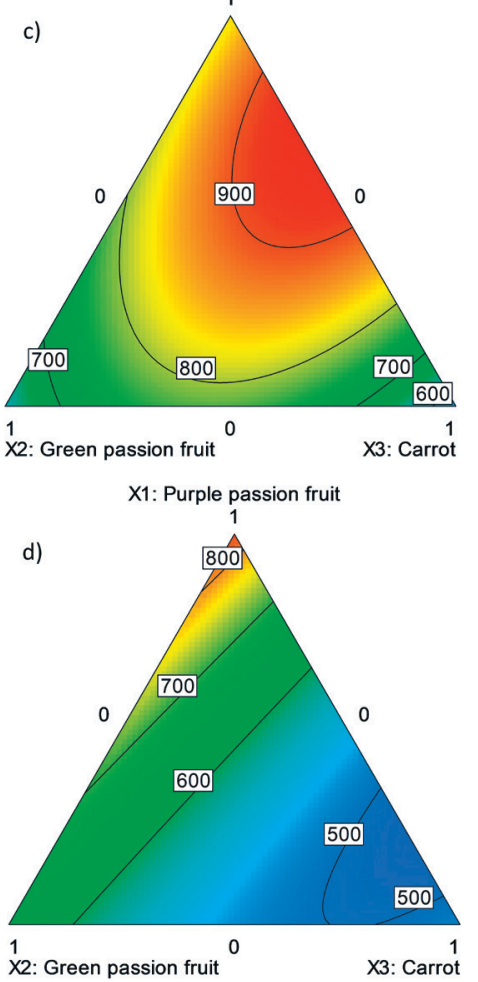

Fig. 1. The effect of the formulation of a drink made from purple passion fruit juice, green passion fruit juice and carrot juice treated by: a) high hydrostatic pressure $\left(500 \mathrm{MPa}, 250 \mathrm{~s}, 25^{\circ} \mathrm{C}\right)$, and pasteurisation: b) $\left.P_{1}\left(65^{\circ} \mathrm{C}, 10 \mathrm{~min}\right), \mathrm{c}\right) \mathrm{P}_{2}\left(75^{\circ} \mathrm{C}, 2 \mathrm{~min}\right)$ and d) $\mathrm{P}_{3}\left(95^{\circ} \mathrm{C}, 1 \mathrm{~min}\right)$ on the antioxidant capacity determined by FRAP method (expressed as Trolox equivalent in $\mathrm{mg} / \mathrm{L}$ ) 
beverage was lower than that obtained by Abountiolas and do Nascimento Nunes (28) for the pomegranate juice Lakewood Pure Pomegranate (Lakewood Juices, Inc.) (8214.01 $\mathrm{mg} / \mathrm{L})$, but higher than that of orange juice Minute Maid Orange Juice (Coca Cola Company) $(509.70 \mathrm{mg} / \mathrm{L})$.

\section{Results of DPPH assay}

Only two of the models achieved coefficients of determination higher than 0.8 (Table 2). Nevertheless, although it is not possible to determine the effect of the formulation on the antioxidant capacity of the beverage treated with methods $\mathrm{P}_{2}$ and $\mathrm{P}_{3}$, it is observed that the antioxidant capacity decreased for all the models of the experimental design, which allows inferring that the increase in temperature affects the antioxidant capacity of the mixtures, generating models and contour graphs with values lower than those obtained in HHP and $\mathrm{P}_{1}$ treatments (Fig. 2).

According to Figs. $2 a$ and $2 b$, the juice of purple passion fruit is the raw material that provides the greatest antioxidant capacity, while the carrot juice has the lowest values. These results are similar to those of the FRAP assay.

On the other hand, mixture 7 was the one which showed the highest antioxidant capacity (Table 1), since it contains the highest volume fraction of purple passion fruit juice. This quantification exceeds the antioxidant capacity determined for untreated pineapple juice ((1096 \pm 193$) \mathrm{mg} / \mathrm{L})(29)$ and white wines $((445.52 \pm 7.51) \mathrm{mg} / \mathrm{L})$, similar to that of red wine ((1379.1 \pm 2.5$) \mathrm{mg} / \mathrm{L})(27)$. In addition, the antioxidant capacity of the formulation exceeds the one determined for the blueberry and raspberry juice Fuze Slenderize Blueberry and Raspberry (Coca Cola Company) (814.94 mg/L), while it is lower than the pomegranate-based drinks ( $7854.83 \mathrm{mg} / \mathrm{L}$ ) Lakewood Pure Pomegranate (Lakewood Juices, Inc.) (28).

\section{Determination of vitamin C concentration}

With the obtained results (Table 1), the statistical models with the best fit (Table 2 ) were generated $\left(R^{2}\right.$ adj $\geq 0.86$ and model with $\mathrm{p} \leq 0.002$ in the $\mathrm{F}$ test) and the respective contour graphs (Fig. 3) were plotted. From the above, it is possible to affirm that, using all conservation methods, purple passion fruit juice contributes to the formulation with the greatest concentration of L-ascorbic acid, followed by green passion fruit juice and finally carrot juice. Additionally, none of the graphs show possible synergistic effects among components. Nevertheless, according to Fig. 3d, an antagonistic effect between green passion fruit and carrot is observable, which is especially noted when there is a low volume fraction of purple passion fruit in the mixture.

The concentration of L-ascorbic acid in the formulations was also affected by the conservation process, and the methods which showed higher vitamin $C$ concentration in the decreasing order were HHP and $\mathrm{P}_{2}$ (Figs. 3a and 3c). The results confirm the degradation of ascorbic acid during thermal treatments, as reported by some authors $(13,30)$, which
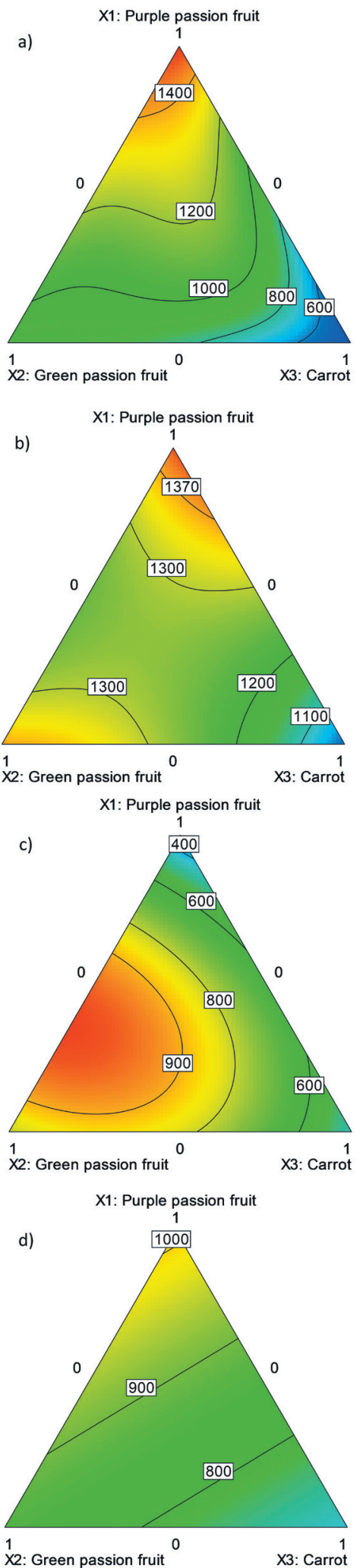

Fig. 2. The effect of the formulation of a drink made from purple passion fruit juice, green passion fruit juice and carrot juice treated by: a) high hydrostatic pressure $\left(500 \mathrm{MPa}, 250 \mathrm{~s}, 25^{\circ} \mathrm{C}\right)$, and pasteurisation: b) $\left.P_{1}\left(65^{\circ} \mathrm{C}, 10 \mathrm{~min}\right), \mathrm{c}\right) \mathrm{P}_{2}\left(75^{\circ} \mathrm{C}, 2 \mathrm{~min}\right)$ and d) $\mathrm{P}_{3}\left(95^{\circ} \mathrm{C}, 1 \mathrm{~min}\right)$ on the antioxidant capacity determined by DPPH method (expressed as Trolox equivalent in $\mathrm{mg} / \mathrm{L}$ ) 

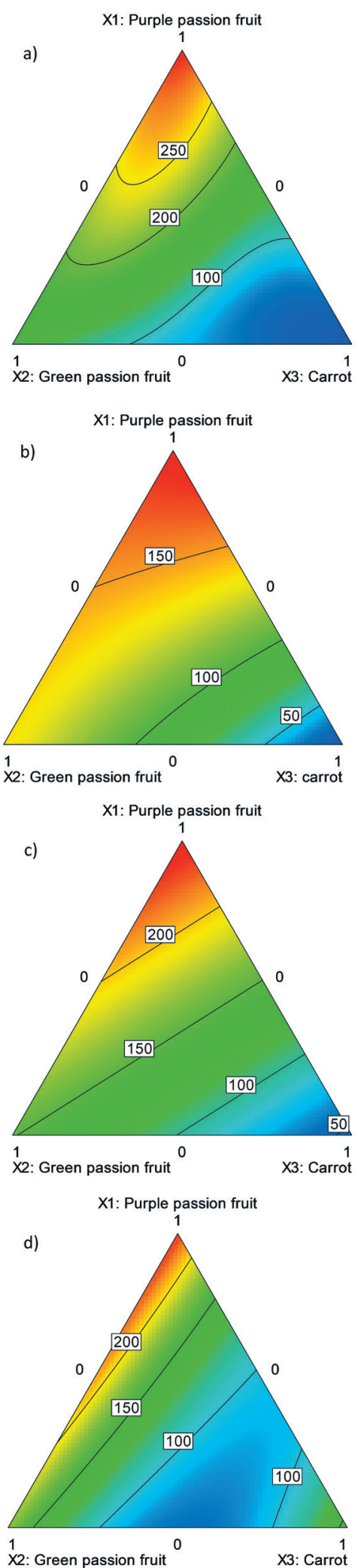

Fig. 3. The effect of the formulation of a drink made from purple passion fruit juice, green passion fruit juice and carrot juice treated by: a) high hydrostatic pressure $\left(500 \mathrm{MPa}, 250 \mathrm{~s}, 25^{\circ} \mathrm{C}\right)$, and pasteurisation: b) $\left.\mathrm{P}_{1}\left(65^{\circ} \mathrm{C}, 10 \mathrm{~min}\right), \mathrm{c}\right) \mathrm{P}_{2}\left(75^{\circ} \mathrm{C}, 2 \mathrm{~min}\right)$ and d) $\mathrm{P}_{3}\left(95^{\circ} \mathrm{C}, 1 \mathrm{~min}\right)$ on the L-ascorbic acid content (expressed as L-ascorbic acid in $\mathrm{mg} / \mathrm{L}$ ) is notable in $\mathrm{P}_{3}$ method compared to HPP (Figs. 3a and 3d) at $25^{\circ} \mathrm{C}$. On the other hand, prolonged times of exposure to high temperatures show decreases in the vitamin $C$ concentration, as shown in Fig. 3b, where values are lower than in $P_{2}$ (Fig. $3 c$ ), in spite of the fact that the latter method had a higher temperature for a shorter time interval.

The highest concentration of L-ascorbic acid $(0.24 \mathrm{mg} / \mathrm{g})$ was determined in mixture 7, which was subjected to HPP (Table 1), similar to the results of Rao et al. (30) for peach juice pasteurized at $90{ }^{\circ} \mathrm{C}$ for $1 \mathrm{~min}((263.4 \pm 9.5) \mathrm{mg} / \mathrm{L})$, or those for fresh purple passion fruit juice $(0.29 \mathrm{mg} / \mathrm{g})(31)$. However, the vitamin C concentration of the formulation is lower than what was described for fresh orange juice (536.5 mg/L) (13) and for beverage R.W. Knudsen Mega C (Knudsen \& Sons, Inc.) (4606 mg/L) (28).

\section{Sensory analysis}

According to Table 3, mixtures 7, 8 and 10 exceeded the marketing limit established for all the evaluated characteristics (5). On the contrary, mixture 9 showed the lowest values for the parameters: colour, aroma and general acceptance, while it did not demonstrate significant differences in the flavour in relation to mixtures 7 and 8 . The above shows that the formulations with low carrot content are preferred by the sensory panel.

No significant differences were observed in the colour (5.4 \pm 1.1$)$, flavour (5.0 \pm 1.2$)$ and general acceptance (5.2 \pm 0.8$)$ characteristics, with respect to the applied conservation method. The above did not follow the behaviour reported by Zvaigzne et al. (13), who showed that high temperature pasteurization and short time $\left(130^{\circ} \mathrm{C}\right.$ for $\left.2 \mathrm{~s}\right)$ affect to a lesser extent the sensorial characteristics of orange juice than conventional pasteurization $\left(94^{\circ} \mathrm{C}\right.$ for $\left.30 \mathrm{~s}\right)$. On the other hand, the aroma showed changes depending on the preservation treatments, where the HHP treatment resulted in a significantly higher values $(5.5 \pm 1.2)$ than treatments $P_{2}(5.0 \pm 0.9)$ and $P_{3}$ $(4.9 \pm 1.0)$, which is similar to the findings of Rao et al. (30) in peach juice, where the samples treated with HHP (600 MPa, $10 \mathrm{~min}, 25^{\circ} \mathrm{C}$ ) were better evaluated than the pasteurized beverage $\left((90 \pm 2){ }^{\circ} \mathrm{C}, 1 \mathrm{~min}\right)$. For this reason, it is inferred that the HHP method keeps the aroma of beverages to a greater extent than thermal treatments.

\section{Microbiological assay during storage at $8{ }^{\circ} \mathrm{C}$}

All the mixtures submitted to the four conservation treatments showed a concentration of $<10 \mathrm{CFU} / \mathrm{mL}$ of mesophilic aerobes, as well as moulds and yeasts on day 0 (data not shown). The thermally treated samples showed an increase in the concentration of mesophilic aerobes at 15 days (30-350 $\mathrm{CFU} / \mathrm{mL}$ ), being uncountable after 30 days. There was no evidence of mould and yeast growth during the first 15 days of storage, and after 30 days they were uncountable.

Juices submitted to HHP exhibited a maximum concentration of $15 \mathrm{CFU} / \mathrm{mL}$ during the 60 days of experimentation, 
Table 3. Sensory evaluation of the selected cold-pressed juice formulations

\begin{tabular}{ccccc} 
Parameter & \multicolumn{4}{c}{ Mixture } \\
\cline { 2 - 5 } Colour & 7 & 8 & 9 & 10 \\
Aroma & $(5.4 \pm 1.1)^{\mathrm{a}}$ & $(5.6 \pm 1.0)^{\mathrm{a}}$ & $(5.0 \pm 1.3)^{\mathrm{b}}$ & $(5.6 \pm 1.0)^{\mathrm{a}}$ \\
Flavour & $(5.3 \pm 1.0)^{\mathrm{ab}}$ & $(5.2 \pm 1.1)^{\mathrm{b}}$ & $(4.45 \pm 1.2)^{\mathrm{c}}$ & $(5.6 \pm 0.9)^{\mathrm{a}}$ \\
General acceptance & $(5.0 \pm 1.2)^{\mathrm{b}}$ & $(5.0 \pm 1.1)^{\mathrm{b}}$ & $(4.6 \pm 1.4)^{\mathrm{b}}$ & $(5.5 \pm 1.2)^{\mathrm{a}}$ \\
\hline
\end{tabular}

The same letters in a row denote no significant differences based on a Kruskal Wallis test $(p<0.05)$ and Mann-Whitney U test $(p<0.0083)$

showing a null growth of microorganisms during storage. The above is similar to what was reported for pomegranate juice, where treatments with HHP higher than $350 \mathrm{MPa}$ for $150 \mathrm{~s}$ maintained the mesophilic aerobic parameters, moluds and yeasts below the detection levels during the entire storage period ( $<1.0 \log$ CFU/mL during 35 days) (32). Nevertheless, Patterson et al. (33) further explained that although the use of HHP (500-600 MPa, $1 \mathrm{~min}, 20^{\circ} \mathrm{C}$ ) reduces the microbial population to $4 \log \mathrm{CFU} / \mathrm{mL}$ in carrot juice, the population of microorganisms at $8^{\circ} \mathrm{C}$ increases during storage, with strains of lactic acid bacteria and Gram-positive spore-forming bacteria determined in carrot juice.

\section{CONCLUSIONS}

The mixture composed of purple passion fruit (67\%), green passion fruit (17\%) and carrot (17\%) juices treated at $500 \mathrm{MPa}$ and $25^{\circ} \mathrm{C}$ for $250 \mathrm{~s}$ showed the highest antioxidant capacity expressed as Trolox equivalent ( 899.63 and $1281.69 \mathrm{mg} / \mathrm{L}$ by FRAP and DPPH assay, respectively), vitamin C concentration (242.79 $\mathrm{mg} / \mathrm{L}$ ) and sensory acceptance. The thermal treatments affected the antioxidant capacity and the concentration of vitamin C in the mixtures, while the high hydrostatic pressure preserved these components and demonstrated better results of the aroma evaluation of the formulations and microbial control during storage at $8{ }^{\circ} \mathrm{C}$. For this reason, high hydrostatic pressure presents an emerging technology that does not affect the analysed chemical parameters, preserves the organoleptic properties desired by the consumers, and ensures the harmlessness and extends the shelf life of the food.

\section{FUNDING}

This work was funded by Jorge Tadeo Lozano University, Bogotá, Colombia in the project functional drinks code 834-15-17.

\section{CONFLICT OF INTEREST}

The authors declare that they have no conflict of interest.

\section{AUTHORS' CONTRIBUTION}

C. Marengo-Orozco participated in designing and performing experiments, and processing and interpreting data. M.P. Tarazona-Díaz took part in designing and performing experiments, interpreting data, preparation of manuscript, writing and revising the manuscript, and the final approval of the version to be published. L.I. Rodríguez designed and performed experiments, and processed and interpreted data.

\section{ORCID ID}

C. Marengo-Orozco (1) https://orcid.org/0000-0002-6241-7800 M.P. Tarazona-Díaz @ https://orcid.org/0000-0003-0871-7295

L.I. Rodríguez ㄴ) https://orcid.org/0000-0003-2258-2155

\section{REFERENCES}

1. McCall B, McPartland CK, Moore R, Frank-Kamenetskii A, Booth BW. Effects of astaxanthin on the proliferation and migration of breast cancer cells in vitro. Antioxidants. 2018; 7(10):135.

https://doi.org/10.3390/antiox7100135

2. Liu R, Zheng Y, Cai Z, Xu B. Saponins and flavonoids from adzuki bean (Vigna angularis L.) ameliorate high-fat diet-induced obesity in ICR mice. Front Pharmacol. 2017;8:687. https://doi.org/10.3389/fphar.2017.00687

3. Doungue HT, Kengne APN, Kuate D. Neuroprotective effect and antioxidant activity of Passiflora edulis fruit flavonoid fraction, aqueous extract, and juice in aluminum chloride-induced Alzheimer's disease in rats. Nutrire. 2018; 43(1):23.

https://doi.org/10.1186/s41110-018-0082-1

4. Lien YHH. Juicing is not all juicy. Am J Med. 2013;126(9):755-6. https://doi.org/10.1016/j.amjmed.2013.04.007

5. Caminiti IM, Noci F, Muñoz A, Whyte P, Morgan DJ, Cronin DA, Lyng JG. Impact of selected combinations of non-thermal processing technologies on the quality of an apple and cranberry juice blend. Food Chem. 2011;124(4):1387-92. https://doi.org/10.1016/j.foodchem.2010.07.096

6. Biancaniello M, Popović V, Fernandez-Avila C, Ros-Polski $\mathrm{V}$, Koutchma T. Feasibility of a novel industrial-scale treatment of green cold-pressed juices by UV-C light exposure. Beverages. 2018;4(2):29.

https://doi.org/10.3390/beverages4020029

7. Wang S, Meckling KA, Marcone MF, Kakuda Y, Tsao R. Synergistic, additive, and antagonistic effects of food mixtures on total antioxidant capacities. J Agric Food Chem. 2011; 59(3):960-8.

https://doi.org/10.1021/jf1040977 
8. Pereira ACS, Wurlitzer NJ, Dionisio AP, Soares MVL, Rocha Bastos MS, Alves RE, Brasil IM. Synergistic, additive and antagonistic effects of fruit mixtures on total antioxidant capacities and bioactive compounds in tropical fruit juices. Arch Latinoam Nutr. 2015;65(2):119-127.

9. Tarazona-Díaz MP, Aguayo E. Influence of acidification, pasteurization, centrifugation and storage time and temperature on watermelon juice quality. J Sci Food Agric. 2013; 93(15):3863-9.

https://doi.org/10.1002/jsfa.6332

10. Tarazona-Díaz MP, Alacid F, Carrasco M, Martínez I, Aguayo E. Watermelon juice: Potential functional drink for sore muscle relief in athletes. J Agric Food Chem. 2013;61(31):7522-8. https://doi.org/10.1021/jf400964r

11. Patras A, Brunton NP, O'Donnell C, Tiwari BK. Effect of thermal processing on anthocyanin stability in foods; mechanisms and kinetics of degradation. Trends Food Sci Technol. 2010;21(1):3-11.

https://doi.org/10.1016/j.tifs.2009.07.004

12. Athmaselvi KA, Kumar C, Poojitha P. Influence of temperature, voltage gradient and electrode on ascorbic acid degradation kinetics during ohmic heating of tropical fruit pulp. J Food Meas Charact. 2017;11(1):144-55.

https://doi.org/10.1007/s11694-016-9381-5

13. Zvaigzne G, Kārkliṇa D, Moersel JT, Kuehn S, Krasnova I, Seglina D. Ultra-high temperature effect on bioactive compounds and sensory attributes of orange juice compared with traditional processing. Proc Latv Acad Sci B Nat Exact Appl Sci. 2017;71(6):486-91.

https://doi.org/10.1515/prolas-2017-0084

14. Juarez-Enriquez E, Salmeron-Ochoa I, Gutierrez-Mendez N, Ramaswamy HS, Ortega-Rivas E. Shelf life studies on apple juice pasteurised by ultrahigh hydrostatic pressure. LWT Food Sci Technol. 2015;62(1):915-9.

https://doi.org/10.1016/j.lwt.2014.07.041

15. Błaszczak W, Amarowicz R, Górecki AR. Antioxidant capacity, phenolic composition and microbial stability of aronia juice subjected to high hydrostatic pressure processing. Innov Food Sci Emerg Technol. 2017;39:141-7.

https://doi.org/10.1016/j.ifset.2016.12.005

16. Ferrari G, Maresca P, Ciccarone R. The application of high hydrostatic pressure for the stabilization of functional foods: Pomegranate juice. J Food Eng. 2010;100(2):245-53. https://doi.org/10.1016/j.jfoodeng.2010.04.006

17. Carvajal de Pabón LM, Turbay S, Rojano B, Álvarez LM, Restrepo SL, Álvarez JM, et al. Some Passiflora species and their antioxidant capacity. Rev Cubana Plant Med. 2011; 16(4):354-63 (in Spanish).

18. Ramaiya SD, Bujang JS, Zakaria MH. Assessment of total phenolic, antioxidant, and antibacterial activities of Passiflora species. Sci World J. 2014;2014:167309.

https://doi.org/10.1155/2014/167309
19. Singh DP, Beloy J, Mclnerney JK, Day L. Impact of boron, calcium and genetic factors on vitamin C, carotenoids, phenolic acids, anthocyanins and antioxidant capacity of carrots (Daucus carota). Food Chem. 2012;132(3):1161-70. https://doi.org/10.1016/j.foodchem.2011.11.045

20. Myers RH, Montgomery DC, Anderson-Cook CM. Experiments with mixtures. In: Myers RH, Montgomery DC, Anderson-Cook CM, editors. Response surface methodology: Process and product optimization using designed experiments. New York, NY, USA: Wiley-Interscience; 2002. pp. 17-74.

21. Bernal de Ramírez I. Fruits and vegetables and these products. In: Bernal de Ramírez I, editor. Food analysis. Bogotá, Colombia: Academia Colombiana de Ciencias Exactas, Físicas y Naturales; 1998. pp. 114-6.

22. Benzie IFF, Strain JJ. The ferric reducing ability of plasma (FRAP) as a measure of 'antioxidant power': The FRAP assay. Anal Biochem. 1996;239(1):70-6.

https://doi.org/10.1006/abio.1996.0292

23. Brand-Williams W, Cuvelier ME, Berset C. Use of a free radical method to evaluate antioxidant activity. LWT - Food Sci Technol. 1995;28(1):25-30.

https://doi.org/10.1016/S0023-6438(95)80008-5

24. Design-Expert., v. 9.0, Stat-Ease, Inc., Minneapolis, MN, USA; 2010. Available from: http://www.statease.com.

25. Infostat, v. 2018e, Universidad Nacional de Córdoba (FCAUNC), Córdoba, Córdoba, Argentina; 2018. Available from: https://www.infostat.com.ar/index.php.

26. Kraujalytė V, Venskutonis PR, Pukalskas A, Česonienė $L$, Daubaras R. Antioxidant properties, phenolic composition and potentiometric sensor array evaluation of commercial and new blueberry (Vaccinium corymbosum) and bog blueberry (Vaccinium uliginosum) genotypes. Food Chem. 2015;188:583-90.

https://doi.org/10.1016/j.foodchem.2015.05.031

27. Stratil P, Kubáň V, Fojtová J. Comparison of the phenolic content and total antioxidant activity in wines as determined by spectrophotometric methods. Czech J Food Sci. 2008;26(4):242-53.

https://doi.org/10.17221/1119-CJFS

28. Abountiolas M, do Nascimento Nunez C. Polyphenols, ascorbic acid and antioxidant capacity of commercial nutritional drinks, fruit juices, smoothies and teas. Int J Food Sci Technol. 2018;53(1):188-98.

https://doi.org/10.1111/ijfs.13573

29. Tchuenchieu A, Essia NJJ, Servais M, Dermience M, Kamden SS, Etoa FX, Sindic M. Effect of low thermal pasteurization in combination with carvacrol on color, antioxidant capacity, phenolic and vitamin C contents of fruit juices. Food Sci Nutr. 2018;6(4):736-46.

https://doi.org/10.1002/fsn3.611

30. Rao L, Guo X, Pang X, Tan X, Liao X, Wu J. Enzyme activity and nutritional quality of peach (Prunus persica) juice: 
Effect of high hydrostatic pressure. Int J Food Prop. 2014; 17(6):1406-17.

https://doi.org/10.1080/10942912.2012.716474

31. USDA. Food Composition Databases, United States Department of Agriculture, Agricultural Research Service: 2018. Available from: https://ndb.nal.usda.gov/ndb/nutrients/index.

32. Varela-Santos E, Ochoa-Martinez A, Tabilo-Munizaga G, Reyes JE, Pérez-Won $M$, Briones-Labarca $V$, Morales-Castro J. Effect of high hydrostatic pressure (HHP) processing on physicochemical properties, bioactive compounds and shelf-life of pomegranate juice. Innov Food Sci Emerg Technol. 2012;13:13-22.

https://doi.org/10.1016/j.ifset.2011.10.009

33. Patterson MF, McKay AM, Connolly M, Linton M. The effect of high hydrostatic pressure on the microbiological quality and safety of carrot juice during refrigerated storage. Food Microbiol. 2012;30(1):205-12.

https://doi.org/10.1016/j.fm.2011.09.013 